\title{
Comparison of Different Leaf Preservation Methods To Obtain High Quality DNA From Enset (Ensete Ventricosum (Welw.) Cheesman), A Native And Orphan Food Security Crop In Ethiopia
}

\author{
Alye Tefera Haile \\ Hawassa University College of Agriculture \\ Sylvia Sagen Johnsen \\ Norwegian University of Life Sciiences \\ Mallikarjuna Rao Kovi \\ Norwegian University of Life Sciences \\ Trine Hvoslef-Eide \\ Norwegian University of Life Sciences \\ Bizuayehu Tesfaye \\ Hawassa University College of Agriculture \\ Odd Arne Rognli ( $D$ odd-arne.rognli@nmbu.no ) \\ Norwegian University of Life Sciences Department of International Environment and Development \\ Studies: Norges miljo- og biovitenskapelige universitet Institutt for internasjonale miljo- og \\ utviklingsstudier Noragric https://orcid.org/0000-0002-5787-752X
}

\section{Research}

Keywords: Ensete ventricosum, Leaf preservation, NaCl-CTAB, Silica gel, Ethanol, DNA extraction

Posted Date: August 18th, 2021

DOl: https://doi.org/10.21203/rs.3.rs-786721/v1

License: (c) (i) This work is licensed under a Creative Commons Attribution 4.0 International License. Read Full License 


\section{Abstract}

Background: Enset (Ensete ventricosum (Welw.) Cheesman) is a staple food for more than 20 million Ethiopians and only cultivated in the native indigenous farming systems of Ethiopia. In contrast to other cultivated species in the Musaceae family, enset has been relatively little studied at the molecular level. Application of advanced molecular genetic techniques requires rapid extraction of DNA of high quality and quantity. Fresh, lyophilized tissues, as well as tissues stored in liquid nitrogen are mainly preferred to avoid DNA degradation, thus most of the DNA extraction protocols recommend these types of tissues as starting material. However, such sample processing techniques are difficult to utilize in many developing countries and at collection sites of many endemic plant species, underutilized or orphan crop species like enset. These situations necessitate the development of alternative protocols for leaf preservation and optimized methods for isolating high-quality DNA from dried or preserved leaf samples.

Results: In this study, three different leaf preservation and two DNA extraction methods were compared. Fresh young leaf tissue was preserved using the minor modified saturated $\mathrm{NaCl}-\mathrm{CTAB}$ solution, silica gel or $96 \%$ ethanol at ambient temperature for more than 35 days. Subsequently, DNA was extracted using either the DNeasy Plant Mini Kit or the CTAB method. As compared to silica gel and $96 \%$ ethanol, the minor modified saturated $\mathrm{NaCl}-\mathrm{CTAB}$ solution preserved the quality, quantity, and integrity of enset genomic DNA. This method consistently produced genomic DNA of high-quality and quantity at affordable cost. The DNeasy Plant Mini Kit method was found to be more efficient than the standard CTAB method, being faster and producing genomic DNA of higher quality.

Conclusions: Using saturated $\mathrm{NaCl}-\mathrm{CTAB}$ solution is an accessible, efficient, scalable, and inexpensive way to preserve enset leaves during collection and transportation. The preservation protocol was validated for leaf tissues of all cultivated and wild enset, and Entada landraces. Genomic DNA of high quality and quantity was obtained from preserved enset leaves, which can be used for further downstream applications including PCR and sequencing.

\section{Introduction}

Rapid extraction of high-quality and pure DNA is a prerequisite step for implementing the most advanced molecular techniques used in modern biological research project such as developing molecular markers, genetic mapping, sequencing, and marker-assisted selection [1, 2]. The isolation of pure and intact genomic DNA of high quality and quantity is a limiting factor in many plant molecular genetic studies, mainly for the next generation sequencing platforms, where high-molecular-weight DNA, free of contaminants is required $[3,4]$. Unlike animals and microbes, the DNA extraction methods need to be adjusted to fit each plant species and even to each plant tissue, because of the presence of secondary metabolites. $[5,6]$. Various protocols have been developed for the extraction of genomic DNA from plants, but a universal application has not been developed $[3,7]$. The main cause of variability and modification in DNA extraction protocols such as the CTAB protocol, is the composition of cell walls and intra- and extracellular components [1]. For genetic diversity studies, in many cases, researchers usually collect 
plant materials from different locations or even from different countries. It is critical to preserve biological samples using methods that maintain the integrity of DNA for the longest possible time, especially for endemic plant species mostly present in remote areas that are difficult to collect [8]. Taxa from temperate zones, botanical gardens and major cultivated crops are often well sampled, but species found in the tropics, particularly in remote areas, are poorly represented [9].

Genomic DNA can be extracted from fresh, dried, or preserved plant tissues using various extraction methods. DNA extraction from plants is generally compromised by excessive contamination of secondary metabolites [10]. Therefore, extraction of large quantities of high-quality DNA from plant tissues can be difficult in some species due to the presence of large amounts of phenolic compounds, high levels of DNases and large amounts of organelle DNA [7]. Young and fresh plant tissues are commonly used as sources of high molecular weight genomic DNA as they contain small amounts of secondary metabolites, less polysaccharides and is easier to grind and isolate DNA from compared to older plant tissues [11, 12]. It is possible to use fresh plant material when the laboratory is close to the research sites, the greenhouse, or the growth chamber. However, using fresh tissue samples are often not practical because the collection sites are located far away from the laboratory, leading to the need for preservation of collected samples, and transport to the laboratory where the DNA extraction will be performed. Degradation of genomic DNA and other biochemical processes begin immediately after the tissue is removed from the plant [13]. Fresh, dehydrated, or lyophilized tissues, as well as tissues stored in the liquid nitrogen, are mainly preferred to avoid DNA degradation. Nevertheless, such sample processing is impossible to perform in many developing countries and at locations of many underutilized tropical plant species [14]. In these cases, plant tissue samples are usually preserved and stored at ambient temperature until brought back to the laboratory or cold storage, where already the DNA might be degraded. Therefore, many ecological and biodiversity studies performed in remote areas need different methods to preserve and store leaf materials, prior to molecular analyses in order to prevent DNA degradation [15].

Enset (Ensete ventricosum (Welw.) Cheesman) is only cultivated in the native indigenous farming systems in Ethiopia [16, 17]. It is the staple food for approximately 20 million Ethiopians. Effective preservation methods are essential when sampling tissues from the remote farmers' fields for investigating molecular diversity or other molecular studies. Further, the leaf preservation methods should be compatible with the requirements of commercial and airline shippers [18]. Dried leaf samples and rapid desiccation is a good alternative for storing herbarium samples in the field, however, preserving herbarium samples in silica gel or by drying has resulted in significant degradation of genomic DNA obtained from herbarium specimens $[8,12,18-20]$. Hydrate leaf preservation methods such as ethanol and saturated $\mathrm{NaCl}-\mathrm{CTAB}$ solution have also been tested on samples from various plant species and the results have been inconsistent $[8,11,21]$. Besides, poor leaf preservation method can lead to DNA degradation and co-precipitation of PCR inhibitors $[15,21]$. However, the saturated NaCl-CTAB solution is an important method for the collection of plant samples from remote areas [21]. This method has been proved to be significant for the preservation of DNA samples of taxonomically diverse species [12, 21, 22]. The advantage of this method is that the dry ingredients, both $\mathrm{NaCl}$ and the CTAB chemicals, are easy to obtain and transport to remote areas in developing countries [21]. However, few studies have been 
conducted using this method for leaf preservation and for studying its effects on the quality and quantity of genomic DNA. The quality and quantity of the DNA from the samples also depend on the duration of sampling and storage, and the plant species $[2,8]$.

Most of the DNA extraction protocols, recommends fresh leaf samples for genomic DNA isolation, but this is impossible when the samples are collected in remote geographical areas. These situations necessitate the development of appropriate protocols for leaf preservation and optimized methods for isolation of high-quality DNA from preserved or dried leaf samples. The main objectives of this study were: (1) to find an optimal method for preserving leaf tissues of enset stored at ambient temperature for various time spans; (2) to examine how the preservation methods affects both the quality and quantity of the genomic DNA; and (3) to study the effect of DNA extraction methods on DNA quality and quantity.

\section{Materials And Methods}

\section{Plant samples and treatments}

Enset leaf tissues used for this study were collected from enset plants grown in farmer fields in the Southern Nations, Nationalities and Peoples' Region (SNNPR) state in Ethiopia. The duration of the storage of collected samples varies from 7 to 35 days at ambient temperature (AT) (Table 1). Young fresh leaf material, free from visible fungal and insect damage, was selected from each enset genotype. The collected samples were divided into three parts and preserved using three different methods, i.e., 1) in saturated $\mathrm{NaCl}-\mathrm{CTAB}$ solution (hexadecyltrimethylammonium bromide), 2) in indicator silica gel, and 3) in ethanol (96\%). The saturated $\mathrm{NaCl}-\mathrm{CTAB}$ solution was prepared following the original protocol [21], with minor modifications. Briefly, $550 \mathrm{~g} \mathrm{NaCl}$ was added to $1 \mathrm{~L}$ of tap water, boiled, cooled at ambient temperature, and mixed thoroughly until the salt precipitated. Then, $35 \mathrm{~g}$ of CTAB was added gradually with irregular intervals mixing, until the solution became viscous. $35-40 \mathrm{~mL}$ of the prepared solution was aliquoted into $50 \mathrm{~mL}$ falcon tubes and used for the preservation of tissue samples. A pair of scissors was used to remove leaf samples from the mother plants. The scissors were cleaned with ethanol $(96 \%)$ between independent samples. Fresh cigar-leaf samples harvested from each enset genotype were stored immediately in the $50 \mathrm{~mL}$ tubes containing the saturated $\mathrm{NaCl}$-CTAB preservation buffer. Samples were then placed in a black plastic bag and stored in a dark room at ambient temperature. The second preservation method used orange indicating silica gel (https://www.agmcontainer.com/920013). The silica gel was applied at 10:1 gram ratio for effective leaf preservation [18]. The leaf tissue samples were placed in small tea bags, the tea bags were stapled, and the tea bags were transferred to individual plastic bags containing 50-60 gram of silica gel [23]. The third preservation method used ethanol (96\%). Approximately 2.5 gram of leaf samples were stored in $15 \mathrm{~mL}$ Falcon tubes containing $8 \mathrm{~mL}$ of $96 \%$ ethanol following the protocol described by Bressan et al. [14]. All samples were stored at ambient temperatures during field collection and transportation from the remote farmer fields to the laboratory at the Norwegian University of Life Sciences, Ås, Norway. 
Table 1

Enset (Ensete ventricosum (Welw.) Cheesman) sample location and leaf preservation information

\begin{tabular}{|c|c|c|c|c|c|}
\hline \multirow{2}{*}{$\begin{array}{l}\text { Accessions } \\
\text { name }\end{array}$} & \multirow{2}{*}{$\begin{array}{l}\text { Cultivation } \\
\text { region }\end{array}$} & \multirow{2}{*}{$\begin{array}{l}\text { No. in Fig. } \\
1-8\end{array}$} & \multirow[t]{2}{*}{ Storage method } & \multicolumn{2}{|c|}{ Storage time (days) } \\
\hline & & & & AT & $\begin{array}{l}-20^{\circ} \mathrm{C} \text { with } \\
\text { NaCl-CTAB }\end{array}$ \\
\hline Tsela & South Omo & 1 & $\mathrm{NaCl}-\mathrm{CTAB}$ solution & 21 & 14 \\
\hline Ado & Sidama & 2 & $\begin{array}{l}\mathrm{NaCl}-\mathrm{CTAB} \text { solution and } \\
\text { silica gel }\end{array}$ & 7 & - \\
\hline Chacho & Sidama & 3 & $\begin{array}{l}\mathrm{NaCl}-\mathrm{CTAB} \text { solution and } \\
\text { silica gel }\end{array}$ & 7 & - \\
\hline Dado & Sidama & 4 & $\begin{array}{l}\mathrm{NaCl}-\mathrm{CTAB} \text { solution and } \\
\text { silica gel }\end{array}$ & 7 & - \\
\hline Borbancho & Sidama & 5 & $\mathrm{NaCl}-\mathrm{CTAB}$ solution & 7 & - \\
\hline Bolanicho & Sidama & 6 & $\mathrm{NaCl}-\mathrm{CTAB}$ solution & 7 & - \\
\hline Chacho & Sidama & 7 & $\mathrm{NaCl}-\mathrm{CTAB}$ solution & 14 & 30 \\
\hline Wild & South Omo & 8 & $\mathrm{NaCl}-\mathrm{CTAB}$ solution & 14 & 30 \\
\hline Wild & South Omo & 9 & $\mathrm{NaCl}-\mathrm{CTAB}$ solution & 21 & 60 \\
\hline Mcho & Sidama & 10 & $\mathrm{NaCl}-\mathrm{CTAB}$ solution & 35 & $>270$ \\
\hline Tunakecho & Sidama & 11 & $\mathrm{NaCl}-\mathrm{CTAB}$ solution & 35 & $>270$ \\
\hline Kerta & South Omo & 12 & Ethanol (96\%) & 7 & - \\
\hline Golaa & South Omo & 13 & Ethanol (96\%) & 7 & - \\
\hline Entada & South Omo & 14 & Ethanol (96\%) & 7 & - \\
\hline Entada & South Omo & 15 & Ethanol (\%96) & 7 & - \\
\hline Wusasi & South Omo & 16 & $\mathrm{NaCl}-\mathrm{CTAB}$ solution & 21 & 14 \\
\hline Golaa & South Omo & 17 & $\mathrm{NaCl}-\mathrm{CTAB}$ solution & 21 & 14 \\
\hline Buuka & South Omo & 18 & $\mathrm{NaCl}-\mathrm{CTAB}$ solution & 21 & 14 \\
\hline Zokuma & South Omo & 19 & $\mathrm{NaCl}-\mathrm{CTAB}$ solution & 21 & 14 \\
\hline Dusak & South Omo & 20 & $\mathrm{NaCl}-\mathrm{CTAB}$ solution & 21 & 14 \\
\hline Siknda & South Omo & 21 & $\mathrm{NaCl}-\mathrm{CTAB}$ solution & 21 & 14 \\
\hline Mono & South Omo & 22 & $\mathrm{NaCl}-\mathrm{CTAB}$ solution & 21 & 14 \\
\hline Solka & South Omo & 23 & $\mathrm{NaCl}-\mathrm{CTAB}$ solution & 21 & 14 \\
\hline
\end{tabular}




\begin{tabular}{|c|c|c|c|c|c|}
\hline \multirow{2}{*}{$\begin{array}{l}\text { Accessions } \\
\text { name }\end{array}$} & \multirow{2}{*}{$\begin{array}{l}\text { Cultivation } \\
\text { region }\end{array}$} & \multirow{2}{*}{$\begin{array}{l}\text { No. in Fig. } \\
1-8\end{array}$} & \multirow[t]{2}{*}{ Storage method } & \multicolumn{2}{|c|}{ Storage time (days) } \\
\hline & & & & AT & $\begin{array}{l}-20^{\circ} \mathrm{C} \text { with } \\
\text { NaCl-CTAB }\end{array}$ \\
\hline Entada & South Omo & 24 & $\begin{array}{l}\text { NaCl-CTAB solution and } \\
\text { Ethanol }(96 \%)\end{array}$ & 7 & - \\
\hline Entada & South Omo & 25 & $\begin{array}{l}\text { NaCl-CTAB solution and } \\
\text { Ethanol }(96 \%)\end{array}$ & 7 & - \\
\hline
\end{tabular}

\section{Sample preparation for DNA extraction}

Upon arrival at the laboratory, the minor modified saturated NaCl-CTAB solution was washed off thoroughly with deionized water and excess water wiped off the leaves with dry white wipes (KimberlyClark $^{\mathrm{TM}}$ Professional Kimtech Science ${ }^{\mathrm{TM}}$ ) (Fig. 2b). Leaf samples were put in liquid nitrogen, ground quickly using a pestle and mortar, and the ground powder transferred into $2 \mathrm{~mL}$ microcentrifuge tubes (Eppendorf A.G., Hamburg, Germany) (Fig. 3a). Leaf samples preserved in silica gel were removed from the tea bags (Fig. 2c) and pulverized using a pestle and mortar in liquid nitrogen (Fig. 3b). Leaf samples preserved in ethanol were washed with deionized water, dried with white wipes (Fig. 2d) and pulverized with a pestle and mortar in liquid nitrogen (Fig. 3c). Pestles and mortars were washed and dried before starting each sample preparation, and all pulverized leaf samples stored at $-80^{\circ} \mathrm{C}$ until further analyses. For DNA extraction, $100 \mathrm{mg}$ of pulverized leaf material of each sample preserved in $\mathrm{NaCl}-\mathrm{CTAB}$ and ethanol, and $20 \mathrm{mg}$ of each sample dried in silica gel were used.

\section{DNA extraction and detections}

Total genomic DNA was extracted from the preserved and dried leaf materials using two different DNA extraction methods. The DNeasy Plant Mini Kit (2016) was used following the manufacturer's instructions (QIAGEN, Hilden, Germany); the other method was the CTAB procedure [24, 25]. However, the CTAB method did not show promising results for the preserved and dried enset leaf samples. The DNeasy Plant Mini Kit (2016) method was used for DNA extraction by varying the volume of the AE buffer (from $50 \mu \mathrm{L}$ to $100 \mu \mathrm{L}$ ) and testing various amounts of tissue (50-100 mg) to find the optimum amount of starting material. After removal of the final AW2 washing buffer, the spin column was transferred into a new $2 \mathrm{ml}$ collection tube and centrifuged again for 1 minute at 20,000 $\mathrm{g}$ to remove leftover AW2 washing buffer from the spin column, which can affect downstream applications. Finally, we used a volume of $50 \mu \mathrm{L}$ AE elution buffer with $100 \mathrm{mg}$ fresh preserved enset leaf samples (Table 2 and Fig. 4, Sample ID 1(d)). The DNA of some accessions were extracted from preserved samples after a few days, whereas DNA for others were extracted following longer preservation times up to nine months at $-20^{\circ} \mathrm{C}$ to compare the quality and quantity of DNA (Table 1). 
Table 2

Quantity and quality of genomic DNA obtained using different amounts of tissue and elution buffer volumes, quantified by NanoDrop

\begin{tabular}{|llllll|}
\hline $\begin{array}{l}\text { Sample } \\
\text { ID }\end{array}$ & $\begin{array}{l}\text { Weight } \\
(\mathbf{m g})\end{array}$ & $\begin{array}{l}\text { Volume of elution buffer } \\
(\boldsymbol{\mu L})\end{array}$ & $\begin{array}{l}\text { DNA quantity }(\mathrm{ng} / \\
\boldsymbol{\mu} \text { ) }\end{array}$ & A260/280 & A260/230 \\
\hline $1(\mathrm{a})$ & 125 & 100 & 55.00 & 1.78 & 2.33 \\
\hline $1(\mathrm{~b})$ & 100 & 100 & 55.90 & 1.77 & 2.26 \\
\hline $1(\mathrm{c})$ & 100 & 75 & 62.80 & 1.78 & 2.39 \\
\hline $1(\mathrm{~d})$ & 100 & 50 & 103.10 & 1.78 & 2.02 \\
\hline $1(\mathrm{e})$ & 80 & 80 & 42.50 & 1.79 & 2.70 \\
\hline
\end{tabular}

\section{Qualitative and quantitative analysis of extracted DNA}

The concentration, purity (A260/A280 ratio), and absorbance ratio at 260-280 $\mathrm{nm}$ (A260/A230 ratio) were measured with a Thermo Scientific NanoDrop ${ }^{\text {TM }}$ (ND) 1000 Spectrophotometer (Thermo Fisher Scientific, USA), using $1 \mu \mathrm{L}$ of each sample. According to DNeasy ${ }^{\circledR}$ Plant handbook (2020), a purified DNA has an A260/A280 ratio of 1.7-1.9, indicating high purity of the DNA. The quality and integrity of total genomic DNA was detected using $1 \%(\mathrm{w} / \mathrm{v})$ agarose gel electrophoresis. Finally, the DNA concentration was measured with the Qubit ${ }^{\circledR}$ dsDNA BR assay kit (Q) (Table 5).

Table 5

Quantity and quality of the total genomic DNA extracted with DNeasy Plant Mini Kit and preserved in the minor modified NaCl-CTAB solution quantified by NanoDrop (ND) and Qubit (Q)

\begin{tabular}{|lllll}
\hline \multicolumn{5}{l}{ DNA quantity DNA quality } \\
\hline Sample ID & $\mathrm{Q}(\mathrm{nl} / \mathrm{ml})$ & $\mathrm{ND}(\mathrm{ng} / \mathrm{\mu L})$ & $\mathrm{A} 260 / 280$ & $\mathrm{~A} 260 / 230$ \\
\hline 16 & 0.56 & 71.27 & 1.77 & 2.46 \\
\hline 17 & 0.36 & 54.02 & 1.76 & 2.35 \\
\hline 18 & 0.45 & 59.00 & 1.79 & 2.39 \\
19 & 0.66 & 98.08 & 1.81 & 2.41 \\
\hline 20 & 0.75 & 89.93 & 1.79 & 2.18 \\
\hline 21 & 0.57 & 64.80 & 1.82 & 2.54 \\
\hline 22 & 0.38 & 57.48 & 1.82 & 2.17 \\
\hline 23 & 1.21 & 106.70 & 1.79 & 2.23 \\
\hline
\end{tabular}


To check whether the genomic DNA extracted could be successfully digested with restriction endonucleases the DNA was digested with the restriction enzyme EcoRI. This is important for downstream applications like PCR and sequencing. The digested DNA was checked by electrophoresis on a $1 \%$ agarose gel (Fig. $8 a, b)$.

\section{Results}

\section{Comparisons of leaf preservation methods}

After few days of storage at ambient temperature there were clear differences between the leaf preservation methods as well as the physical appearance of the intact leaf samples (color) (Fig. 2) and pulverized (powder texture) samples (Fig. 3). Moreover, visible biological contamination and infection were not observed on the leaves preserved by all these three methods. Samples preserved with the minor modified saturated $\mathrm{NaCl}-\mathrm{CTAB}$ solution maintained their original leaf color, i.e. the leaves remained green with no browning contrary to the other methods (Fig. 2b, 3a). Leaf samples preserved in silica gel or ethanol did not maintain their visible physical characteristics except for a few samples (Fig. 2). Samples stored in ethanol (96\%) changed their color and formed a sticky and clay-mud like powder following pulverization (Fig. 3c).

\section{Comparison of DNA extraction methods}

Total genomic DNA was extracted from preserved and dried leaves using the DNeasy plant mini kit and the CTAB extraction methods. Agarose gel electrophoresis and NanoDrop showed that total genomic DNA extracted using the DNeasy plant mini kit method gave DNA of high concentration and purity (Fig. 4-8) (Table 3), whereas DNA extracted using the CTAB method showed comparatively lower concentration and purity (Table 3).

Table 3

Comparison of DNA quantity and quality of samples extracted with different extraction methods, quantified by NanoDrop (ND)

\begin{tabular}{|lllll|}
\hline Extraction methods & Storage methods & $\begin{array}{l}\text { DNA quantity } \\
(\mathbf{n g} / \boldsymbol{\mu L})\end{array}$ & A260/280 & A260/230 \\
\hline $\begin{array}{l}\text { Minor modified DNeasy } \\
\text { plant mini kit }\end{array}$ & $\begin{array}{l}\text { Modified saturated } \\
\text { NaCl-CTAB }\end{array}$ & $50.80-222.10$ & $\begin{array}{l}1.70- \\
2.01\end{array}$ & $2.09-$ \\
CTAB method & $\begin{array}{l}\text { Modified saturated } \\
\text { NaCl-CTAB }\end{array}$ & $7.50-9.70$ & $1.99-$ & $-0.67-$ \\
\hline
\end{tabular}

\section{DNA quality and quantity from preserved and dried enset leaves}


The DNA quality and quantity were measured from preserved and dried tissue using NanoDrop and Qubit. Overall, the DNA extracted from samples preserved in saturated $\mathrm{NaCl}-\mathrm{CTAB}$ were of high quality with A260/A280 ratios ranging from 1.70 to 2.01 and concentrations of DNA ranging from 50.83 to $222.1 \mathrm{ng} /$ $\mu \mathrm{L}$ (Table 3). The storage temperature (ambient or $-20^{\circ} \mathrm{C}$ ) had no effect on the quality and quantity of DNA from leaves preserved in saturated NaCl-CTAB (Table 2-5) (Fig. 5, 7, 8). The DNA extracted from samples preserved with different methods appeared as distinct bands separated on the gel at their corresponding high molecular weights with little evidence of shearing and absence of RNA contamination (Fig. 5, 7). However, DNA obtained from dried leaf samples preserved in silica gel and the hydrated leaf samples preserved in ethanol (96\%) stored for 7 days at ambient temperature were highly degraded and not visible on the gel (Fig. 5, 7). Thus, the DNA from these samples were not analyzed further.

Furthermore, we performed digestion of the DNA with the restriction enzyme EcoRI, to further validate that the DNA extracted from leaves preserved using the saturated NaCl-CTAB method can be used in downstream analysis like sequencing and molecular marker development (Fig. 8a, b).

\section{Discussion}

One of the main advantages of the saturated $\mathrm{NaCl}-\mathrm{CTAB}$ solution for preserving enset leaves is the use of common and inexpensive reagents, scalability, and its simplicity of usage. In addition, it was easy to transport samples in this solution from farmer fields in Ethiopia to Norway [21, 26]. To the best of our knowledge, no other studies have been investigating the effects of different enset leaf preservation and DNA extraction methods on the quality, quantity and integrity of DNA extracted from the preserved and dried enset leaf material. In this study, we determined that DNA could be successfully extracted from enset leaves preserved using the minor modified saturated NaCl-CTAB solution for longer periods (over 35 days) at ambient temperature. The NaCl-CTAB solution preserved both the physical properties of the enset leaf samples and high quality and quantity of genomic DNA could be extracted after 7 to 35 days at ambient temperature and from samples stored more than nine months at $-20^{\circ} \mathrm{C}$ (Fig. 5, 7) (Table 4). One of the reasons for slowing down the DNA degradation process using the $\mathrm{NaCl}-\mathrm{CTAB}$ method is attributable to the high salt concentration, which partially dehydrate the leaf tissues. Furthermore, CTAB interacts with nucleic acids, proteins and carbohydrates to slow down the DNA degradation processes [11]. Another reason that the saturated $\mathrm{NaCl}$-CTAB solution might be more suitable for enset leaf preservation than silica gel is the fact that enset has hard leathery leaves with few stomata and high contents of water and fiber [21]. In addition, the solution and the falcon tube protect the enset leaves from shaking and from physical damaged during field collection and transportation, which are important to minimize DNA degradation [21]. Besides, visible contamination was not observed on the enset leaves and this is most likely due to the bactericidal and detergent properties of CTAB, as seen in previous studies, $[21,27]$. Further, the saturated $\mathrm{NaCl}-\mathrm{CTAB}$ leaf preservation method also facilitates cleaning of leaves during the removal of the preservation solution before DNA extraction [27]. On the contrary, it has been shown that other plant species such as Nardus stricta L. (Poaceae), with thick cuticles, were not preserved well using the saturated $\mathrm{NaCl}-\mathrm{CTAB}$ preservation method [22]. This indicates that the rate of degradation varies among plant species and leaf preservation methods [18, 21, 22, 28]. However, enset leaves stored 
in other chemicals such as ethanol (96\%) did not preserve the DNA even after only seven days at ambient temperature (Fig. 5, 7). This might be because ethanol did not facilitate and induce leaf lysis, cell wall disruption, and deactivation of DNAases during field collection and transportation $[29,30]$. Similarly, Pyle and Adams (1989) found that preservation of spinach leaves in $95 \%$ ethanol for as little as $24 \mathrm{~h}$ resulted in significant DNA degradation [20]. On the contrary, Bressan et al. found that Jatropha curcas and other tropical species can be successfully preserved in ethanol for up to 30 days [14].

Table 4

Control of DNA quantity and quality among different leaf preservation methods and seven days stored at ambient temperature, quantified by NanoDrop (ND)

\begin{tabular}{|c|c|c|c|c|}
\hline Sample ID & Storage methods & DNA quantity (ng/ $\mu \mathrm{L})$ & A260/280 & A260/230 \\
\hline $11 \mathrm{~s}$ & Silica Gel (orange color) & 87.70 & 1.82 & 2.31 \\
\hline $12 \mathrm{~s}$ & & 72.77 & 1.76 & 1.94 \\
\hline $16 s$ & & 66.02 & 1.87 & 1.98 \\
\hline $11 \mathrm{c}$ & Saturated $\mathrm{NaCl}-\mathrm{CTAB}$ & 72.98 & 1.73 & 2.02 \\
\hline $12 \mathrm{c}$ & & 43.68 & 1.70 & 2.04 \\
\hline $16 c$ & & 72.80 & 1.70 & 1.79 \\
\hline $24 e$ & Ethanol (96\%) & 32.37 & 1.72 & 2.04 \\
\hline $25 e$ & & 58.92 & 1.79 & 2.08 \\
\hline $24 c$ & Saturated $\mathrm{NaCl}-\mathrm{CTAB}$ & 97.39 & 1.78 & 2.27 \\
\hline $25 c$ & & 54.62 & 1.71 & 2.32 \\
\hline
\end{tabular}

This study showed that the DNA quality of the samples preserved in silica gel were highly degraded compared to the samples preserved in the minor modified saturated $\mathrm{NaCl}-\mathrm{CTAB}$ solution (Fig. 5, 7). Most likely the preservation efficiency of silica gel is affected by the enset leaf secondary compounds or tissue characteristics [31], as most tropical plant species contain considerable amounts of secondary compounds $[3,14]$. As pointed out, enset has hard leathery leaves with high contents of water and fiber, and the natural shape of the young cigar leaf. Another reason might be that enset is a highly drought tolerant species and will not easily desiccated by the silica gel [32,33]. Other studies have reported DNA degradation in other plant tissues preserved in silica gel due to the accumulation of phenolic compounds, which interfere with the quality of the isolated DNA $[15,26,29]$. However, preservation in silica gel works in some plant species such as grasses and small herbs [18, 34, 35]. All this shows that different plant species require specific leaf preservation methods and the efficiency of each leaf preservation method can vary among and within plant species $[18,21,22]$. 
Regarding the DNA extraction methods, the DNeasy Plant Mini Kit (Qiagen) is more suitable for large number of DNA samples with limited time compared to the CTAB method $[35,36]$. In the present study, we used both solvent (CTAB) and solid (Qiagen kit) phase DNA extraction (SPE) methods [37]. The total genomic DNA extracted using the DNeasy plant mini kit method gave DNA of higher concentrations and purities than DNA extracted using the CTAB method (Table 3). This indicates that most likely the CTAB method is better for young and fresh leaves than preserved leaf samples [2]. The second reason might be that the DNA extracted using the DNeasy Plant Mini Kit method most likely is free from secondary metabolites that interfere with the quality and quantity of DNA [38]. Most secondary compounds in plant tissues affect the disruption of tissues, interferes with the DNA extraction, reduce the DNA quality and inhibit subsequent molecular analyses like PCR and sequencing $[7,14]$.

Overall, we obtained DNA of high quality and quantity when we used the NaCl-CTAB preservation method combined with DNeasy Plant Mini Kit (Qiagen) extraction method from leaf samples of enset stored for variable length of time and at various temperatures (ambient and $-20^{\circ} \mathrm{C}$ ). We also tested that the DNA obtained was suitable for downstream applications (Fig. 8a, b). Further, we observed little contamination by polysaccharides and proteins as indicated by the ratios of A260/A230 and A260/A280 (Table 2-5). When we compared the effect of different leaf preservation methods, i.e., saturated $\mathrm{NaCl}$-CTAB solution, silica gel and ethanol, we found that only the saturated $\mathrm{NaCl}-\mathrm{CTAB}$ solution had slight degradation after 7 to 35 days of storage at ambient temperature, whereas the other two methods showed significant degradation after the same storage time (Fig. 5, 7). The difference between these three leaf preservation methods became clear after seven days storage times at ambient temperature (Fig. 5, 7). This indicates that saturated $\mathrm{NaCl}-\mathrm{CTAB}$ solution can preserve enset DNA without causing severe degradation. The spectrophotometric measurements with NanoDrop tend to give higher readings of DNA quality and quantity of DNA from tissue preserved in silica gel and ethanol (Table 4), most likely due to contamination with the molecules absorbed at $260 \mathrm{~nm}$ or the interferences of proteins, and the NanoDrop reading degraded DNA [39]. Moreover, DNA purity can be severely affected by various components of sample matrices such as polysaccharides, lipids, and polyphenols or extraction chemicals like CTAB [40].

\section{Conclusions}

An efficient leaf preservation and DNA extraction method for enset leaf material is described. Based on the results, the minor modified saturated $\mathrm{NaCl}-\mathrm{CTAB}$ leaf preservation method was found to be a better field preservation method for maintaining freshness, and integrity, quality and quantity of DNA of enset samples than preservation in silica gel or $96 \%$ ethanol. Further, this method makes the transportation of the samples from remote areas easy. The method consistently produces high yield and high-quality genomic DNA of enset at an affordable cost. Also, we found that the DNeasy plant mini kit approach performed better in extracting high quality and quantity of enset genomic DNA than the CTAB method. The high-quality genomic DNA extracted using this method, was used for further downstream applications including PCR and sequencing. Therefore, our results provided useful suggestions for preservation methods and DNA extraction methods. 


\section{Declarations}

\section{Ethics approval and consent to participate}

Collection and utilization of the plant material follow the Ethiopian biodiversity guidelines and have been approved by the Ethiopian Biodiversity Institute.

\section{Consent for publication}

Not applicable.

\section{Availability of data and material}

All data generated or analysed during this study are included in this published article [and its supplementary information files].

\section{Competing interests}

The authors declare that they have no competing interests.

\section{Funding}

The authors thank the Norwegian Agency for Development Cooperation (Norad) for funding this study which is part of the project "Controlling disease in sweet potato and enset in South Sudan and Ethiopia to improve productivity and livelihoods under changing climatic conditions using modern technologies" under the NORHED program (Agreement No. ETH-13/0017).

\section{Authors' contributions}

ATH collected plant materials, did the laboratory work, drafted, and revised the manuscript. SSJ and MRK supervised the laboratory work, read, and corrected the manuscript. BT participated in designing the study, reading, and correcting the manuscript. THE acquired funding, read, and corrected the manuscript. OAR took part in designing the study, reading, and correcting the manuscript. All authors approved the submitted version.

\section{Acknowledgements}

The authors would like to thank Øyvind Jørgensen and Anne Guri Marøy for excellent technical support.

\section{References}

1. Pervaiz Z, Turi N, Khaliq I, Rabbani M, Malik S. GMR mr: Methodology: a modified method for highquality DNA extraction for molecular analysis in cereal plants. Genet Mol Res. 2011;10(3):1669-73.

2. Guo Y, Yang G-Q, Chen Y-M, Li D-Z, Guo Z-H. A comparison of different methods for preserving plant molecular materials and the effect of degraded DNA on ddRAD sequencing. Plant Divers. 
2018;40:106-16.

3. Abdel-Latif A, Osman G. Comparison of three genomic DNA extraction methods to obtain high DNA quality from maize. Plant Methods. 2017;13(1):1.

4. Vaillancourt $B$, Buell CR. High molecular weight DNA isolation method from diverse plant species for use with Oxford Nanopore sequencing. BioRxiv 2019,783159, doi: doi.org/10.1101/783159.

5. Sangwan N, Sangwan R, Kumar S. Isolation of genomic DNA from the antimalarial plant Artemisia annua. Plant Mol Biol Rep. 1998;16(4):365-5.

6. Sönmezoğlu ÖA, Terzi B. Comparison of DNA extraction protocols for PCR-based techniques in wheat. EUR J LIPID SCI TECH. 2019(17):860-865.

7. Varma A, Padh H, Shrivastava N. Plant genomic DNA isolation: an art or a science. Biotechnol J. 2007;2(3):386-92.

8. Doyle JJ, Dickson EE. Preservation of plant samples for DNA restriction endonuclease analysis. Taxon. 1987, 36(4):715-722.

9. Harris SA. evolution: DNA analysis of tropical plant species: an assessment of different drying methods. Plant Syst Evol. 1993;188(1-2):57-64.

10. Sahu SK, Thangaraj M, Kathiresan KN: DNA extraction protocol for plants with high levels of secondary metabolites and polysaccharides without using liquid nitrogen and phenol. INT SCH RES NOTICES. 2012, 2012: 6.

11. Almakarem ASA, Heilman KL, Conger HL, Shtarkman YM, Rogers SO. Extraction of DNA from plant and fungus tissues in situ. BMC Res Notes. 2012;5(1):266.

12. Nickrent DL. From field to film: rapid sequencing methods for field-collected plant species. Biotechniques. 1994;16(3):470-5.

13. Rogers SO, Abu Almakarem AS, Heilman KL, Conger HL, Shtarkman YM. Extraction of DNA from Plant and Fungus Tissues in situ. BMC Research Notes. 2012, 5(266).

14. Bressan EA, Rossi ML, Gerald LT, Figueira A. Extraction of high-quality DNA from ethanol-preserved tropical plant tissues. BMC Res Notes. 2014;7(1):268.

15. Bainard L, Klironomos J, Hart M. Differential effect of sample preservation methods on plant and arbuscular mycorrhizal fungal DNA. J Microbiol Methods. 2010;82(2):124-30.

16. Brandt S, Spring A, Hiebsch C, McCabe JT, Tabogie E, Diro M, Wolde-Michael G, Yntiso G, Shigeta M, Tesfaye S. The "Tree Against Hunger": Enset-based agricultural systems in Ethiopia. Washington: American Association for the Advancement of Science; 1997.

17. Guzzon F, Müller JV. Current availability of seed material of enset (Ensete ventricosum, Musaceae) and its Sub-Saharan wild relatives. Genet Resour Crop Evol. 2016;63(2):185-91.

18. Chase MW, Hills HH. Silica gel: an ideal material for field preservation of leaf samples for DNA studies. Taxon. 1991;40(2):215-20.

19. Liston A, Rieseberg LH, Adams RP, Do N, Ge-lin Z. A method for collecting dried plant specimens for DNA and isozyme analyses, and the results of a field test in Xinjiang, China. Ann Mo Bot Gard. 
1990;77(4):859-63.

20. Pyle MM, Adams RP. In situ preservation of DNA in plant specimens. Taxon. 1989:576-581.

21. Rogstad SH. Saturated NaCl-CTAB solution as a means of field preservation of leaves for DNA analyses. Taxon. 1992;41:701-8.

22. Štorchová H, Hrdličková R, Chrtek J Jr, Tetera M, Fitze D, Fehrer J. An improved method of DNA isolation from plants collected in the field and conserved in saturated $\mathrm{NaCl} / \mathrm{CTAB}$ solution. Taxon. 2000;49:79-84.

23. Goldberg L, Weintraub S. Regulations Change for Cobalt Indicating Silica Gel. AIC Objects Specialty Group Postprint. 2001;26(1):14.

24. Kovi MR, Zhang Y, Yu S, Yang G, Yan W, Xing Y. Candidacy of a chitin-inducible gibberellin-responsive gene for a major locus affecting plant height in rice that is closely linked to Green Revolution gene sd1. Theor Appl Genet. 2011;123(5):705-14.

25. Murray $M$, Thompson WFJNar. Rapid isolation of high molecular weight plant DNA. Nucleic Acids Res. 1980;8(19):4321-6.

26. Bhattacharjee R, Ferguson M, Gedil M, Dumet D, Ingelbrecht I. Field collection, preservation and large scale DNA extraction procedures for cassava (Manihot esculenta Crantz.). Afr J Biotechnol. 2009, $8(15)$.

27. Thomson JA. An improved non-cryogenic transport and storage preservative facilitating DNA extraction from 'difficult'plants collected at remote sites. Telopea. 2002;9(4):755-60.

28. Till BJ, Jankowicz-Cieslak J, Huynh OA, Beshir MM, Laport RG, Hofinger BJ. Low-Cost Methods for Molecular Characterization of Mutant Plants. Cham: Springer; 2015. pp. 9-11.

29. Akinnagbe A, Ji XB, Yang M, Ewald D. Ethanol pretreatment increases DNA yields from dried tree foliage. Conserv Genet Resour. 2011;3(3):409-11.

30. York WS, Darvill AG, McNeil M, Stevenson TT, Albersheim P. Isolation and characterization of plant cell walls and cell wall components. Meth Enzymol. 1986;118:3-40.

31. Savolainen V, Cuénoud P, Spichiger R, Martinez MD, Crèvecoeur M, Manen J-F. The use of herbarium specimens in DNA phylogenetics: evaluation and improvement. Plant Syst Evol. 1995;197(1-4):8798.

32. Borrell JS, Biswas MK, Goodwin M, Blomme G, Schwarzacher T, Heslop-Harrison JSP, Wendawek AM, Berhanu A, Kallow S, Janssens S, et al. Enset in Ethiopia: a poorly characterized but resilient starch staple. Ann Bot. 2019;123(5):747-66.

33. Adams RP, Zhong M, Fei Y. Preservation of DNA in plant specimens: inactivation and re-activation of Dnases in field specimens. Mol Ecol. 1999;8(4):681-3.

34. Laulier M, Pradier E, Bigot Y, Periquet G. An easy method for preserving nucleic acids in field samples for later molecular and genetic studies without refrigerating. J Evol Biol. 1995;8(5):657-63.

35. Margam VM, Gachomo EW, Shukle JH, Ariyo 00, Seufferheld MJ, Kotchoni SO. A simplified arthropod genomic-DNA extraction protocol for polymerase chain reaction (PCR)-based specimen identification 
through barcoding. Mol Biol Rep. 2010;37(7):3631-5.

36. Kotchoni SO, Gachomo EW. A rapid and hazardous reagent free protocol for genomic DNA extraction suitable for genetic studies in plants. Mol Biol Rep. 2009;36(6):1633-6.

37. TOPÇU A, AŞIR S. TÜRKMEN D: DNA Purification by Solid Phase Extraction SPE Methods. J Biol Chem. 2016;44(3):259-66.

38. Sika KC, Kefela T, Adoukonou-Sagbadja H, Ahoton L, Saidou A, Baba-Moussa L, Baptiste LJ, Kotconi So, Gachomo EW. A simple and efficient genomic DNA extraction protocol for large scale genetic analyses of plant biological systems. Plant Gene. 2015;1:43-5.

39. Ponti G, Maccaferri M, Manfredini M, Kaleci S, Mandrioli M, Pellacani G, Ozben T, Depenni R, Bianchi G, Pirola GM. The value of fluorimetry (Qubit) and spectrophotometry (NanoDrop) in the quantification of cell-free DNA (cfDNA) in malignant melanoma and prostate cancer patients. Clin Chim Acta. 2018;479:14-9.

40. Vinson C, Mangaravite E, Sebbenn A, Lander T. Using molecular markers to investigate genetic diversity, mating system and gene flow of Neotropical trees. Braz J Bot. 2018;41(2):481-96.

\section{Figures}




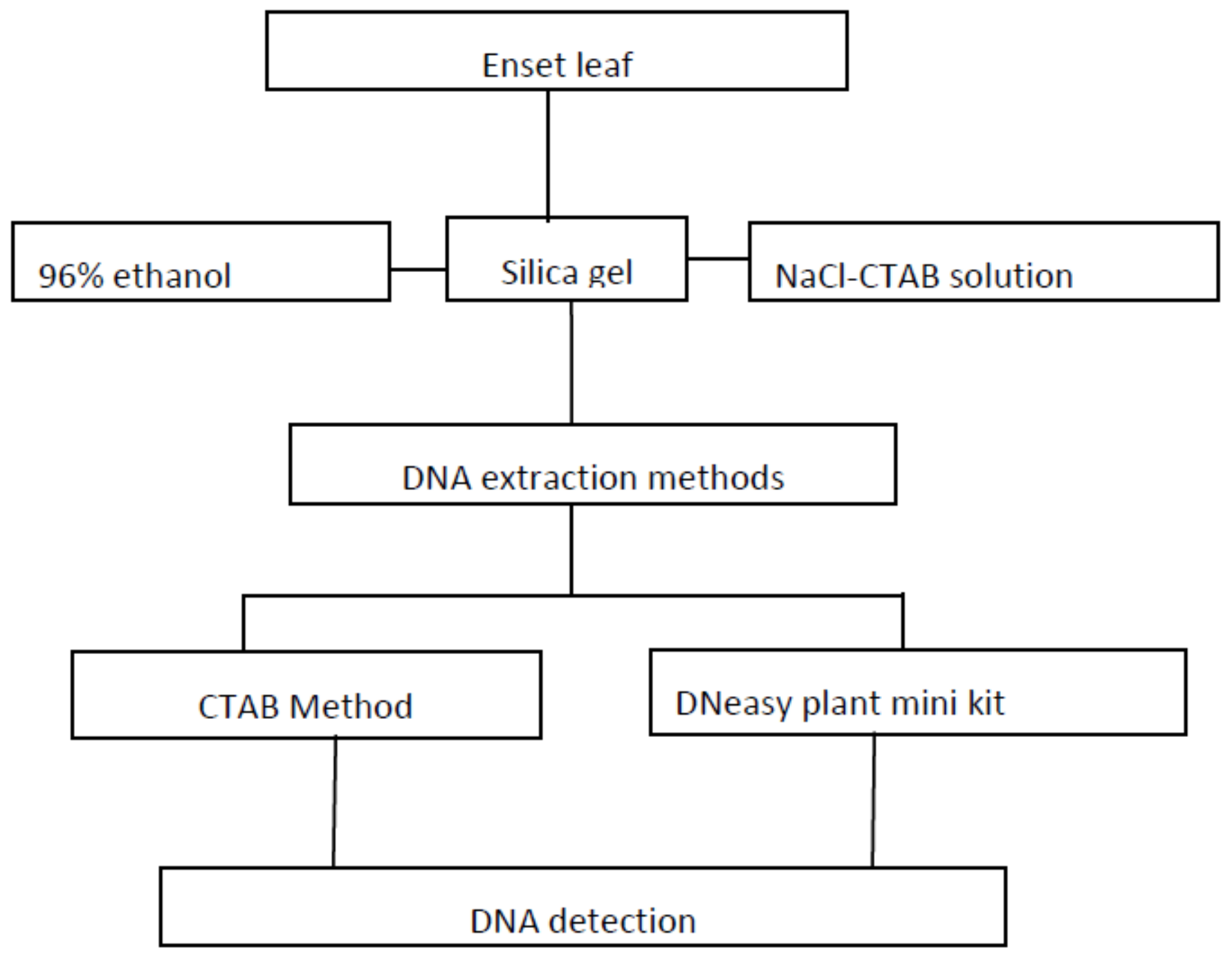

Figure 1

Flowchart of workflow design 

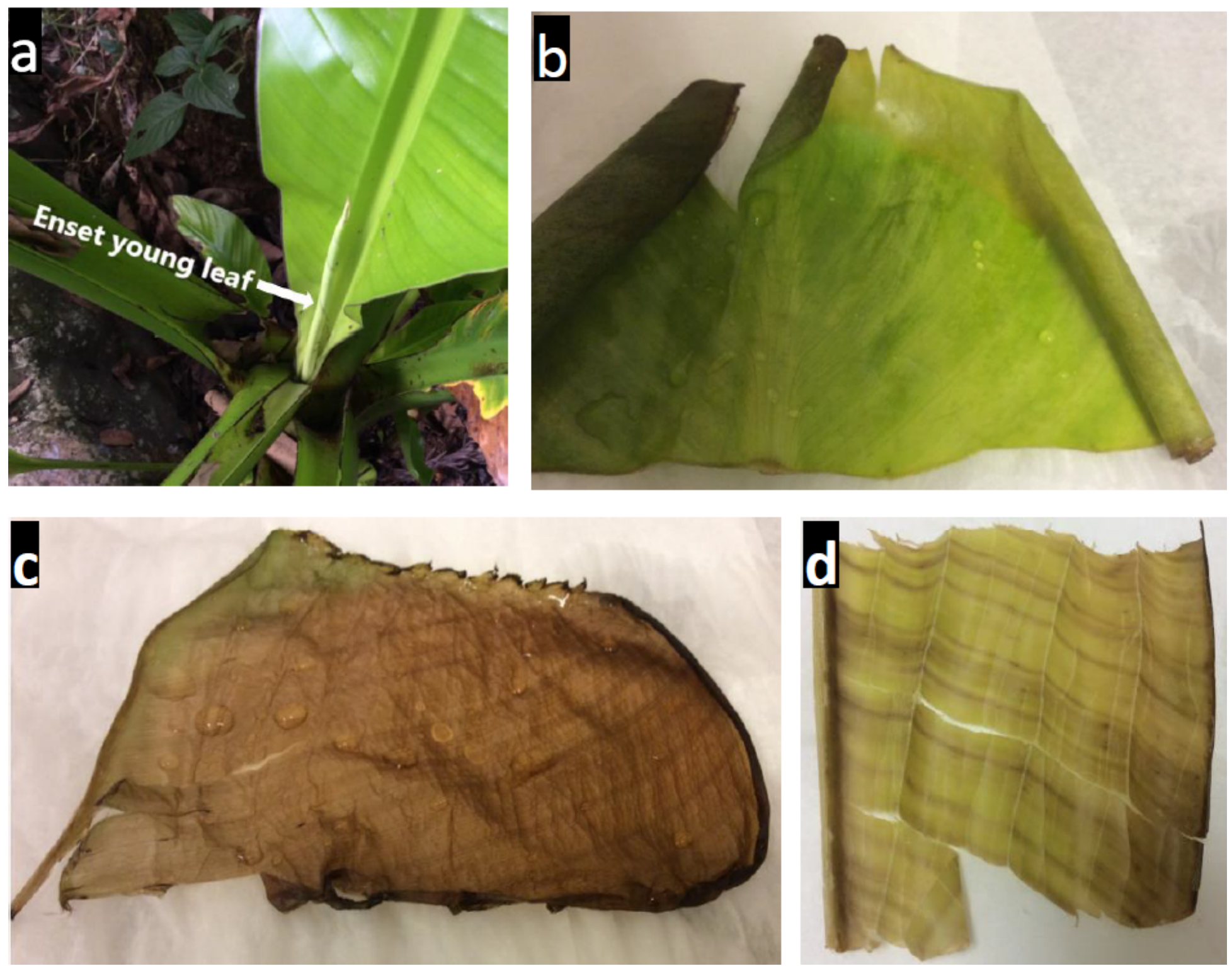

Figure 2

Enset plant and preserved enset leaves after seven days of storage at ambient temperature. The external structure of the enset plant and enset young leaf used for preservation and DNA extraction (a), preserved in saturated $\mathrm{NaCl}-\mathrm{CTAB}$ solution (b), preserved in silica gel (c), preserved in ethanol (96\%) (d) 

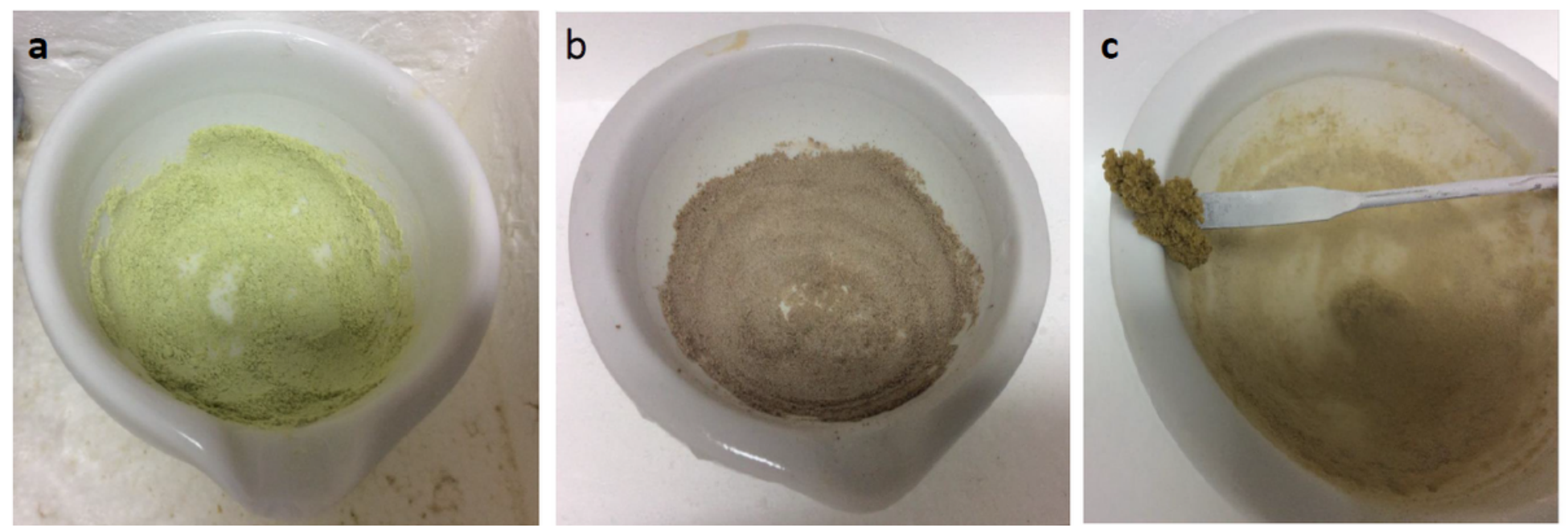

\section{Figure 3}

Pulverized enset leaf samples after seven days of storage at ambient temperature. Preserved in saturated $\mathrm{NaCl}-\mathrm{CTAB}$ solution (a), silica gel (b) and ethanol (96\%) (c)

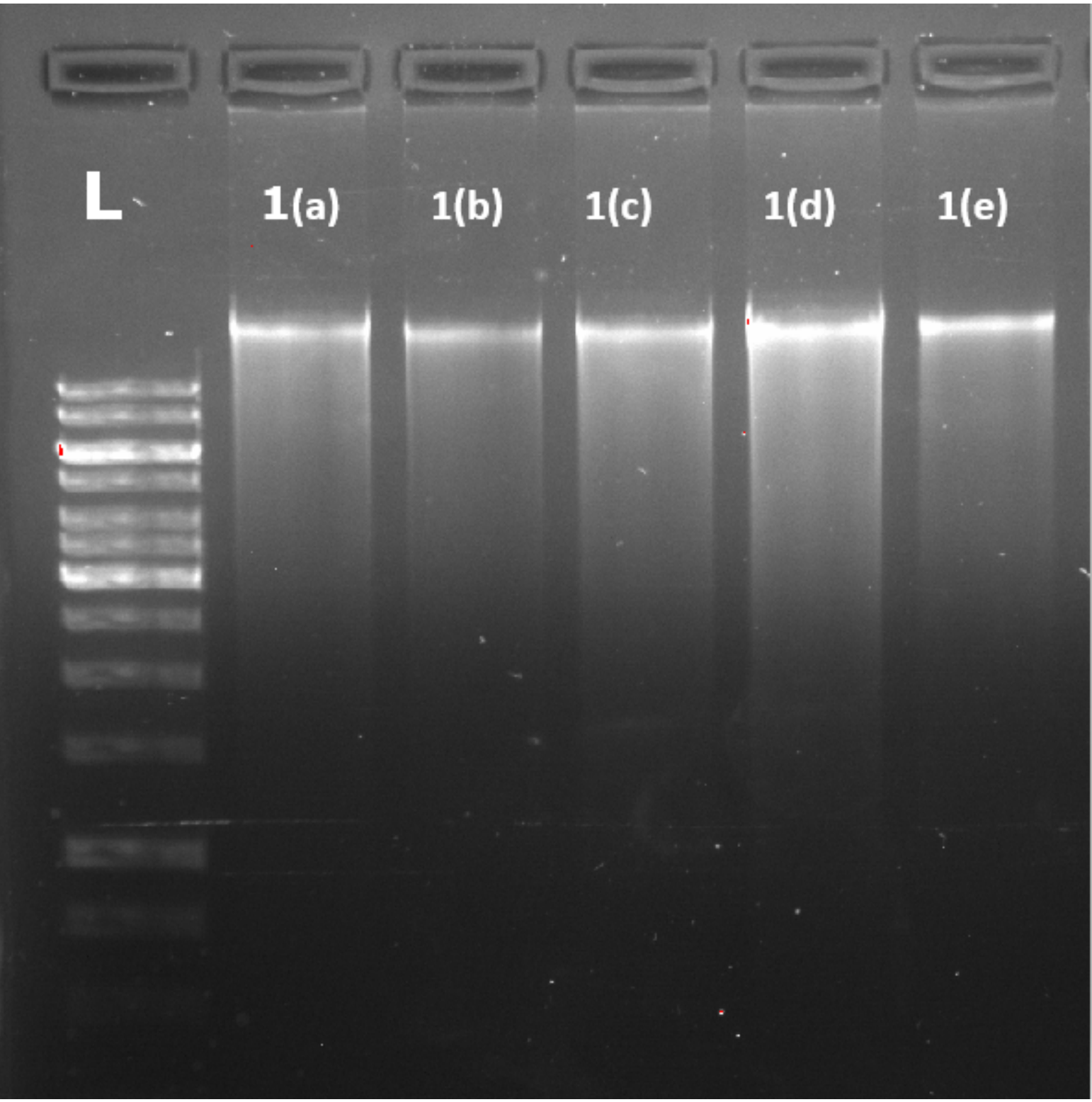




\section{Figure 4}

Agarose gel electrophoresis of total genomic DNA extracted with the DNeasy Plant Mini Kit. Lanes 1(a) to 1 (e) correspond to the samples in Table 2 with different combinations of amount of leaf material and elution buffer (AE), i.e. 1 (a) $125 \mathrm{mg} / 100 \mu \mathrm{L}, 1$ (b) $100 \mathrm{mg} / 100 \mu \mathrm{L}, 1$ (c) $100 \mathrm{mg} / 75 \mu \mathrm{L}, 1$ (d) $100 \mathrm{mg} / 50 \mu \mathrm{L}$, 1 (e) $80 \mathrm{mg} / 80 \mu \mathrm{L}$. L, $1 \mathrm{~kb}$, DNA molecular weight ladder (Thermo). Accession that corresponds to the number is shown in Table 1

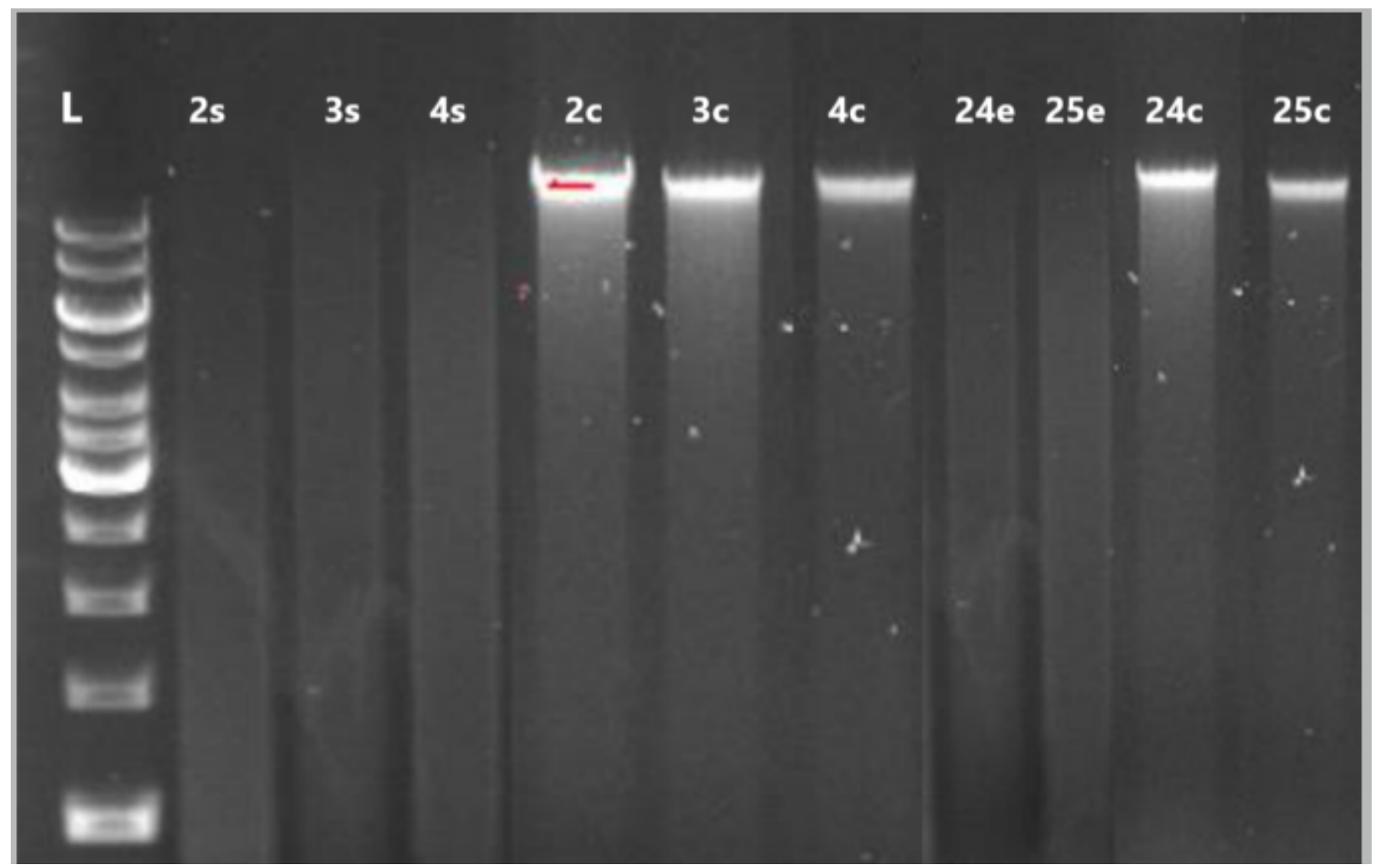

Figure 5

Agarose gel (1\%) electrophoresis of total genomic DNA extracted from preserved leaf by the DNeasy Plant Mini Kit following different leaf preservation methods but the same genotype and the same storage period (seven days) at ambient temperature (AT). Samples are stained with $1 \mu \mathrm{L}$ Red safe; L: 1kb DNA molecular weight ladder (Thermo), s: silica gel, c: NaCl-CTAB solution and e: ethanol (96\%). Accession names that correspond to the numbers are described in Table 1 

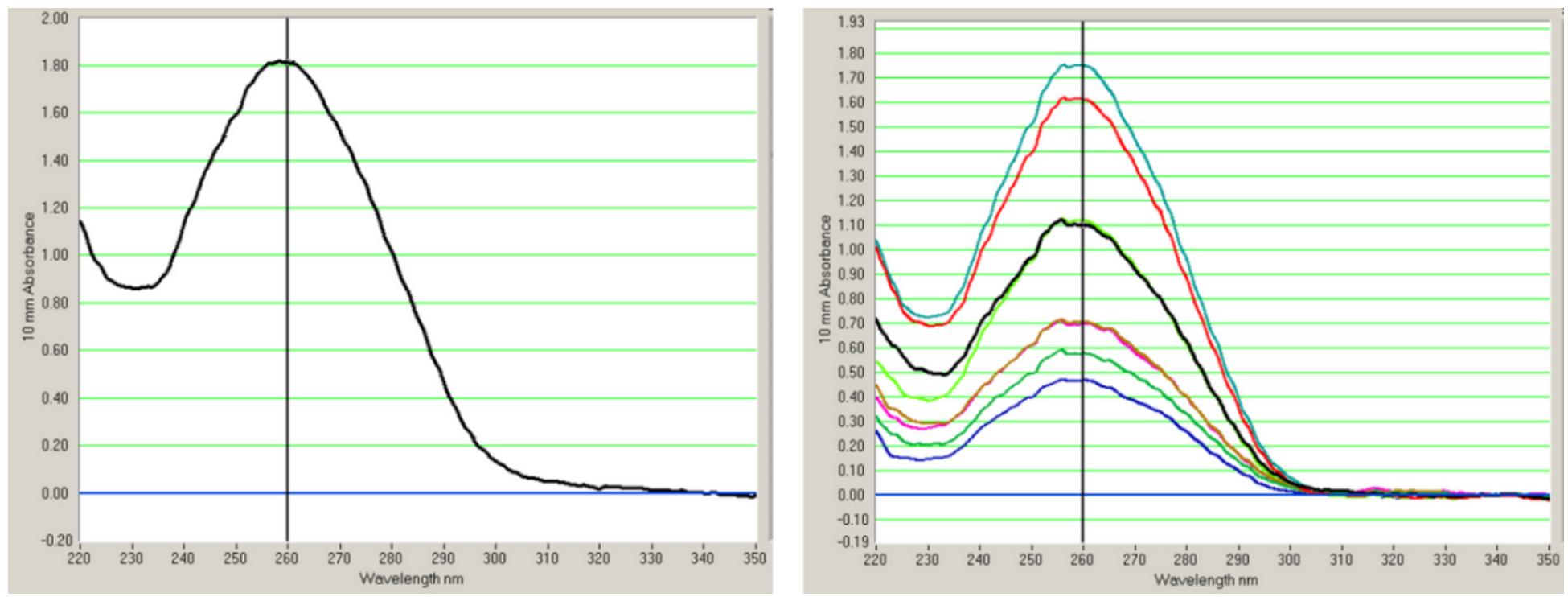

Figure 6

Nano-Drop measurement profile of genomic DNA extractions from preserved leaves in saturated $\mathrm{NaCl}$ CTAB solution. DNA extracted by using DNeasy Plant Mini Kit method. Scanned on NanoDrop from 220 to $350 \mathrm{~nm}$

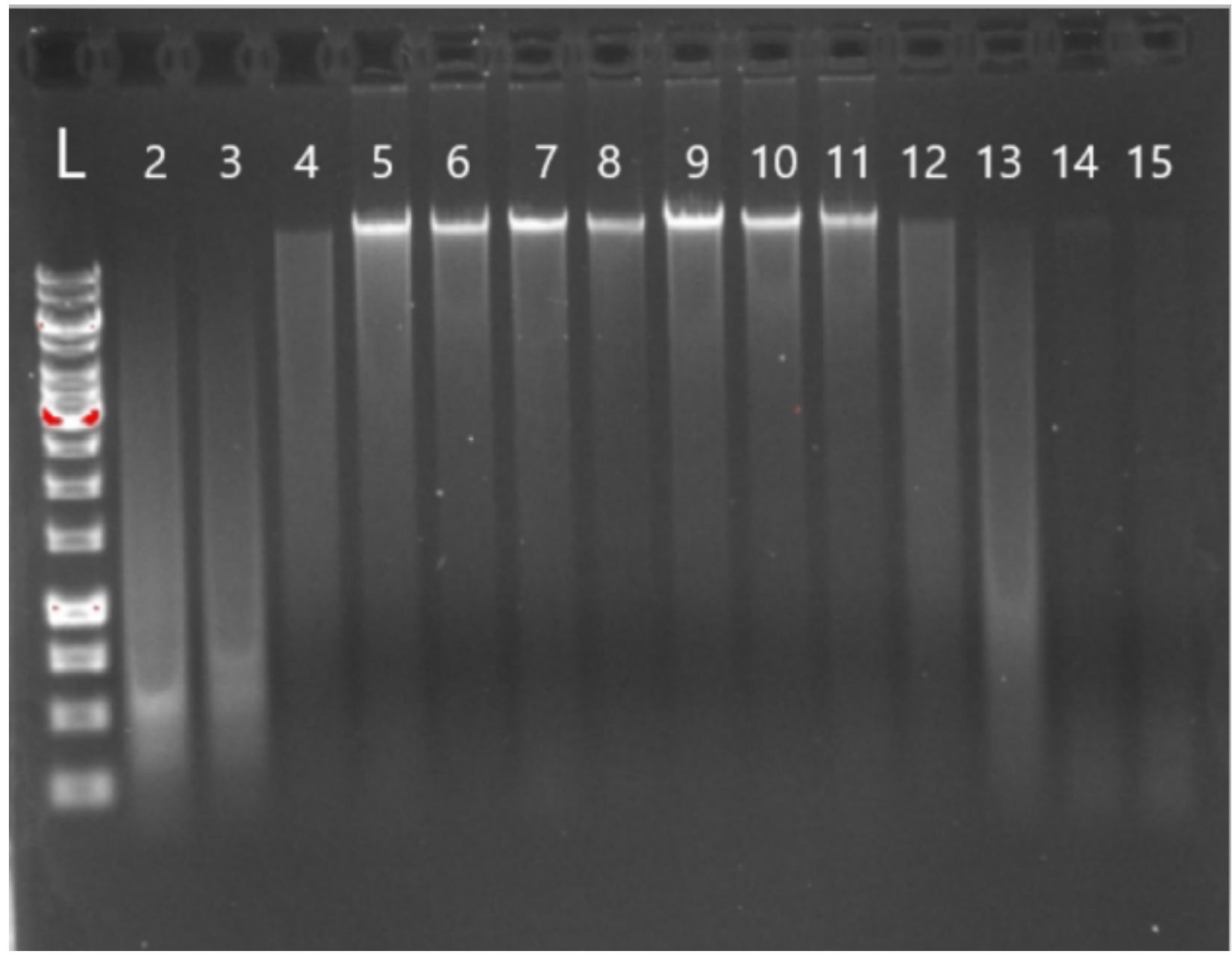

Figure 7 
Agarose gel (1\%) electrophoresis of total genomic DNA extracted from preserved leaves by the DNeasy Plant Mini Kit following different duration of preservation. Lanes 2-4: Silica gel preserved leaf after seven days at ambient temperature (AT), Lanes 5-6: 7 days preserved in NaCl-CTAB at AT, Lanes 7-8: preserved for 14 days at AT and stored 30 days at $-20^{\circ} \mathrm{C}$ in NaCl-CTAB, Lane 9: preserved for 21 days at AT and stored 60 days at $-20^{\circ} \mathrm{C}$ in NaCl-CTAB, Lanes 10-11: preserved for 35 days at AT and stored $>270$ days $-20^{\circ} \mathrm{C}$ in NaCl-CTAB, Lanes 12-15: ethanol (96\%) preserved leaf after 7 days AT, L: $1 \mathrm{~kb}$, DNA molecular weight ladder (Thermo). Samples are stained with $1 \mu \mathrm{L}$ Red safe. Accessions corresponding to the numbers (2-15) are described in Table 1

\section{Image not available with this version}

\section{Figure 8}

we obtained DNA of high quality and quantity when we used the NaCl-CTAB preservation method combined with DNeasy Plant Mini Kit (Qiagen) extraction method from leaf samples of enset stored for variable length of time and at various temperatures (ambient and $-20^{\circ} \mathrm{C}$ ). We also tested that the DNA obtained was suitable for downstream applications (Fig. a, b). 